\title{
ANALYSIS OF SOCIOECONOMIC STATUS, GENDER, AND ACADEMIC ACHIEVEMENTS INFLUENCE ON STUDENT CAREER MATURITY
}

UDC 159.923.2.072-057.875

\section{Muhammad Abdul Ghofur, Ady Soejoto, Heni Purwa Pamungkas}

Universitas Negeri Surabaya, Faculty of Economics and Business, Surabaya, Indonesia

\begin{abstract}
Career maturity is defined as a person's ability to identify and prepare for a career choice. Career maturity will be necessary for students because as the level of career maturity increases, the achievement of their work will also increase. This study aims to determine the factors that influence student career maturity. The type of research used is correlational research with quantitative methods. Data were collected using a questionnaire method and data analysis techniques using multiple linear regression. The results of the regression analysis showed that gender variables influenced career maturity, while academic achievement and socioeconomic status do not have a significant influence on student career maturity.
\end{abstract}

Key words: Career Maturity, Academic Achievement, Socioeconomic Status.

JEL Classification: J16, A23, O15.

\section{INTRODUCTION}

An increase in the number of graduates with no education is accompanied by an increase in the absorption of teacher personnel, resulting in increasingly fierce levels of competition for graduate education. In response to this, career maturity is essential for students. Simply stated, career maturity is interpreted as a person's ability to determine and prepare for their chosen career. Super and Knasel (1981) say that career maturity defines as readiness in determining career choices, attitudes, and competencies as well as relevant information needed in determining career choices.

Creed (2001) states that career maturity includes the ability of individuals to make appropriate career choices, including considerations when making reliable and consistent

Received April 08, 2020 / Revised April 21, 2020 / Revised June 13, 2020 / Accepted June 22, 2020

Corresponding author: Muhammad Abdul Ghofur

Department of Economics Educations, Universitas Negeri Surabaya, Indonesia

E-mail: muhammadghofur@unesa.ac.id 
decisions. Besides, career maturity also involves various aspects of a person. Janeiro (2010) states that the development of one's career behavior requires complex processes, including interactions between cognitive, motivational, and affective dimensions. The cognitive dimension consists of decision-making skills, while the affective dimension includes attitudes in the decision-making process.

Furthermore, Super and Knasel (1981) divided the stages of a person's career development into five stages, namely: (1) the stage of growth at the age of 0-14 years; (2) the exploration stage when someone is 14-24 years old; (3) stabilization stage; (4) maintaining stage; and (5) the release stage. At the exploration stage, there are three sub-stages, namely: the tentative stage when a person is $15-17$ years old, then the crystallization stage of job choices, and the stage of job choice specifications. At each stage, some separate tasks and characteristics must be fulfilled.

Determination of one's career maturity is influenced by various aspects, including socioeconomic status, parental support, gender, academic achievement, learning motivation, and so on. These factors determine the level of maturity in one's career. There has not been much research that examines the factors that influence student career maturity.

Choi et. al (2012) state that parental support has a positive effect on a person's career maturity. Parent intervention influences decisions in determining careers. Other research conducted by Luzzo (1995) examined the impact of gender differences on the career maturity of students; the results of this study stated that there were differences in career maturity between male and female students. Nevertheless, empirically there are still many differences in the career maturity levels of male and female students in various contexts.

Some studies state that there is no significant difference in career maturity between male and female students, for example, the research of Lee and Hughey (2001). Research conducted by Jawarneh (2016) revealed the same results. The study involved 284 students in Jordan, with a majority of female participants as much as $91.5 \%$ (260 students) and men as little as $8.5 \%$ (24 students). The study concluded that there were no differences in the level of career maturity based on gender. Still, there were differences in the dimensions of career planning between second-year students and final year students. Heo and Kim (2016) conducted a study to examine the relationship between self-esteem and adolescent career maturity in South Korea. This longitudinal study was carried out over four years and used stratified multistage cluster sampling in determining samples. The results of the study stated that there were differences in the level of self-esteem of participants from year to year. Still, there were no differences in the level of career maturity between female and male participants.

On the other hand, several studies have different results from the above studies. Other studies suggest that women are more mature than men, as Lee (2001) and Patton and Creed (2003) research. In line with the results of the above study, the research of Yon, Choi, and Goh (2013) shows that gender and socioeconomic status variables correlate with one's career maturity. But in the analysis conducted by previous researchers, the career maturity of students from various levels of social status is relatively the same, or there is no real difference, even though students from higher socioeconomic status have lower career maturity levels (Rinanda and Ghofur, 2019).

As previously mentioned, the research conducted by Jawarneh (2016) in Jordania and Heo and Kim (2016) in South Korea equally concluded that gender does not affect the level of career maturity. The results were in contrast to the research conducted by Koumoundourou, Kounenou, and Siavara (2012), stating that there is a difference in career maturity between male and female students. The research of Patton and Creed (2002) examining the level of 
career maturity involving 377 adolescents in Australia, also concluded that girls have a higher score than teenage boys in terms of career planning, workplace information, and career decision-making. Research related factors affecting the level of career maturity have different outcomes. Many factors affect the difference in these outcomes. Therefore, current research aims to continue previous research.

When viewed in terms of age, according to Super and Knasel (1981), students enter a period of crystallizing work tendencies, that is, a time when someone already has realistic considerations when entering the workforce, choosing work preferences, and developing realistic self-concepts. Career maturity is essential for students to have because it will have an impact on work performance. A well-prepared career will have a positive effect on future career success (Spurk et al. 2015). As the level of career maturity gets higher, the achievement of one's work will also increase. On the contrary, when the level of career maturity is low, the individual does not have a plan regarding what career will be chosen, what competencies are needed, and how to prepare to achieve the chosen career.

Based on observations in the field, not all students have a high level of career maturity. There are still students who do not yet have a career planning or grasp of the future. How to prepare themselves, whether the chosen majors by the field of work should be pursued, as well as what skills are needed to achieve that career. Also, some students do not even know what they will become after graduating from college. So, when they enter the world of work, there are students who work not following the area of expertise learned during college, though learning on campus is an integral part of one's career (Stephen and Burke, 1994).

The learning experience on campus is also very closely related to how students can build their careers; students who focus on learning related to the chosen career can develop careers more easily (Kim and Shin, 2020). The learning experience will also encourage students to strive for optimal learning outcomes; of course, they will try to get the best grades in those lectures that are closely related to their chosen career. The value of learning outcomes is often considered a measure of one's competence (Chhinzer and Russo, 2018; Rothman, 2017).

Knowing the level of student career maturity is needed by various parties, especially managers of a university. Knowing some critical factors related to student career maturity can be important initial information for future learning policymaking. Career maturity plays a vital role in the stages of one's career development. The ability to determine and prepare for a career needs to be conditioned to run according to the stages. Therefore, this study aims to examine the relationship between socioeconomic status, gender, and academic achievement on student career maturity.

\section{LITERATURE REVIEW}

\subsection{Career Maturity}

Crites and Savickas (1996) state that career maturity is the ability and readiness of a person to determine their career choices both now and in the future, whereas Patton and Creed (2001) state that career maturity includes the ability of individuals to make appropriate career choices, including considerations when making reliable and consistent decisions. A person's career maturity can be used to measure the level of affective and cognitive career development that has been achieved. Janeiro (2010) states that the development of one's career behavior involves complex processes, including interactions 
between cognitive, motivational, and affective dimensions. "The cognitive dimension consists of decision-making skills, while the affective dimension includes attitudes in the decision-making process." Crites (1973) argues that a person's career maturity divided can be seen in five aspects. Namely: "(a) involvement in the choice process; (b) orientation toward work; (c) Independence in decision making; (d) preference for vocational choice factors; and (e) conception of the choice process."

Career choice and development is an essential process in implementing one's selfconcept (Super 1980). The concept of self is a very complex interaction of several factors, including physical and mental development, personal experience, and environmental characteristics. In its development, a person's career stage can be divided into five stages. Other opinions about the stages of career maturity come from Cobb and Yvette (2008), who stated that a person's career development would go through seven phases, namely: Exploration, Personal Assessment, Analysis, Decision Making, Planning, Implementation, and Management of the world of work.

Another career development theory was coined by Gottfredson (2002), which states that choosing a career is a process that requires a high level of cognitive ability. Gottfredson's theory combines innate characteristics with the surrounding environment. A person's career inspiration is more influenced by the surrounding environment (e.g., gender, social status) than the personal aspects of self-concept (e.g., skills and interests). There are four stages in the process of one's career development, including: "(1) Orientation to size and power, (2) orientation to sex-roles, (3) Orientation to social valuation, (4) Orientation to the internal."

Another theory was coined by Lent (2013), who described the relationship between people and the environment. The theory is better known as the Social Cognitive Career Theory (SCCT). This theory explains three things, namely: (a) academic and vocational development; (b) how individuals choose Education and careers; (c) Career education and performance. Furthermore, SCCT explained that the development of career goals and choices as a function of the interaction between self-efficacy expected outcomes and interests. Choosing a career is a process in which the environment and individuals influence one another. This involves career choices or goals, actions to achieve those goals, and individual experiences that match the objectives.

\subsection{Socioeconomic Status}

Based on the Social Cognitive Career Theory (SSCT), socioeconomic status is an aspect that affects the development of one's self-efficacy. The family's socioeconomic status is associated with a person's achievement/strata in community life. Individuals who have a high level of socioeconomic status will have the opportunity to gain higher education, support parents, and have more role models in selecting jobs (Hsieh and Huang 2014). Some research has proved that parent support variables and family structures as indicators of family socioeconomic status have an essential role in the development of adult careers. The research conducted by Metheny and McWhirter (2013) proved that family socioeconomic status and family support influenced career development. The study involved 270 male and female students. The variable predictor used is a family socioeconomic status, family support, the intensity of career-related family interactions.

Contrary to the research conducted by Hsieh and Huang (2014) and also Metheny and McWhirter (2013), several studies have different results. Research conducted (Patel et al., 2008) reveals that gender, parental support, family social support, and socioeconomic status 
do not contribute to the self-efficacy of career decision making. The study took a sampling of teenagers in Vietnam, of 85 people. Another study by Shin and Lee (2018) also gave similar results. The study tested gender variables, socioeconomic status, classism, and locus of control as contributing factors to student career selection. The study involved 139 students. The results of the survey stated that (a) gender and socioeconomic status did not contribute significantly to the self-efficacy of student career selection, (b) classism and modern sexism contributed to student career selection. It indicated that classism and modern sexism are more critical than the socioeconomic status in predicting the self-efficacy of student career selection. Indicators of Socioeconomic Status can be measured through three variables: parents' income, parental education level, and parental work (Sirin 2005). Parents' income is an SES indicator that describes the resources available to students in education.

\subsection{Academic Achievement}

Academic achievement is one of the measures of learning outcomes at formal institutions. Academic achievement is also associated with lower stress, higher self-concept, higher self-efficacy, and health. Academic achievement is essential to achieving learning objectives at school. Also, academic achievement can be interpreted as a person's achievement in the dimension of knowledge, skills, and behavior. It is reflected in the mastery of knowledge and skills on a particular subject. Rugutt and Chemosit (2005) stated that several factors are affecting academic achievement, namely: early student skills, motivation, age, teaching instruction quality, learning climate, etc.

\section{MethodolOGY}

This is a correlational study, whereas when viewed from the angle of the approach or method used, it was quantitative. The model of this research is explained in figure 1 . The independent variable in this study is socioeconomic status $\left(\mathrm{X}_{1}\right)$, gender $(\mathrm{D})$, and academic achievement $\left(\mathrm{X}_{2}\right)$. The dependent variable is career maturity $(\mathrm{Y})$. Gender is a variable with a nominal scale, so in the analysis, it uses regression dummy variable analysis. Chen, et.all (2018) state that socioeconomic status is measured from three dimensions, namely: family income, parental education level, and parental occupation, while the academic cumulation index regulates academic achievement in the last semester of students. While the data analysis technique used is multiple linear regression analysis techniques with dummy variables.

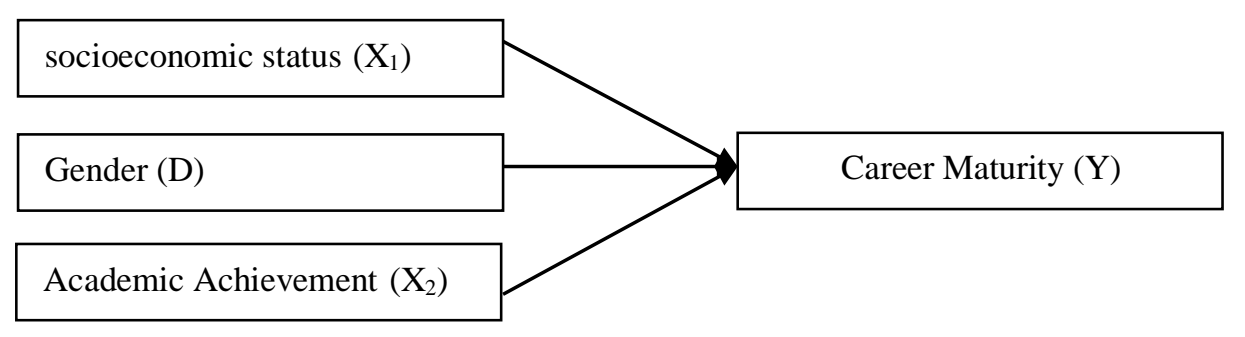

Fig. 1 Research Model 
The population of this study was all active students of the Faculty of Economics, Universitas Negeri Surabaya. Total students who meet the criteria as a population amounts to 947 students. Data were taken from 175 students in 4 different programs - determination of respondents who became the study sample using the Stratified Random Sampling method.

The data collection method in this study uses a closed questionnaire. The questionnaire contains age-related information, gender, parental income, and parental education. Also, the poll comes with a question to measure the maturity level of the student career socioeconomic status. The variable item of student career maturity was developed by the researchers based on the Career Maturity Inventory of Savickas and Porfeli (2011). The student's socioeconomic status was measured by several indicators, namely: Father's education, father's income, father's job, mother's education, mother's job, and mother's income. The level of parental education was divided into four levels: Junior high School, High School, Undergraduate, and Postgraduate. The academic achievement variables of this study were measured based on the Academic Achievement Index in the last semester of the student. The academic achievement data is taken directly from the data owned by the campus administration.

\section{RESULT AND DISCUSSION}

The level of student career maturity is still mostly in the medium category. In table 1 . it can be seen that only $8 \%$ of students categorized as having good career maturity. The remaining $92 \%$ still need attention because they have not prepared their careers well. Most of them, if they graduate later, will possibly face a pretty hard time in tackling the competition.

Table 1 Frequency distribution for student career maturity

\begin{tabular}{rcrrr}
\hline \multicolumn{1}{c}{ Interval } & Midpt & Frequency & \multicolumn{1}{c}{ Rel. } & \multicolumn{1}{c}{ Cum. } \\
\hline$<32.250$ & 27.000 & 1 & $0.57 \%$ & $0.57 \%$ \\
$32.250-42.750$ & 37.500 & 10 & $5.71 \%$ & $6.29 \%$ \\
$42.750-53.250$ & 48.000 & 65 & $37.14 \%$ & $43.43 \%$ \\
$53.250-63.750$ & 58.500 & 85 & $48.57 \%$ & $92.00 \%$ \\
$>=63.750$ & 69.000 & 14 & $8.00 \%$ & $100.00 \%$ \\
\hline
\end{tabular}

From table 2 that illustrates the distribution of the cumulative value index of students, it is known that this range of values is divided into five interval ranges. There was only one person with an index <2.45, students with grades between 3.24-3.64 are 141 people, and students with grades $>3.6$ are 27 people. Overall, the average student score was 3.49 . The value of this student, when compared to the size of the index value in Indonesia, is outstanding. Regardless of how students obtain these grades, this value index is often a requirement in applying for jobs.

Table 2 Frequency distribution for academic achievements

\begin{tabular}{rccrr}
\hline \multicolumn{1}{c}{ Interval } & Midpt & Frequency & Rel. & Cum. \\
\hline$<2,4575$ & 2,2600 & 1 & $0,57 \%$ & $0,57 \%$ \\
$2,4575-2,8525$ & 2,6550 & 0 & $0,00 \%$ & $0,57 \%$ \\
$2,8525-3,2475$ & 3,0500 & 6 & $3,43 \%$ & $4,00 \%$ \\
$3,2475-3,6425$ & 3,4450 & 141 & $80,57 \%$ & $84,57 \%$ \\
$>=3,6425$ & 3,8400 & 27 & $15,43 \%$ & $100,00 \%$ \\
\hline
\end{tabular}


Female students dominated the students who became the sample of this study. $82.86 \%$ of the sample were female, and $17.14 \%$ were male. This information is a picture of the general condition in universities, where most of their study programs are scientific fields in education in Indonesia.

The socioeconomic status of the respondents is depicted in table 3. Most respondents come from families with socioeconomic status down to the middle. As many as $78.86 \%$ of them are in the lower and middle socioeconomic status indicating that they are in a reasonably stable socioeconomic environment.

Table 3 Frequency distribution for socioeconomic status

\begin{tabular}{rcrr}
\hline & Frequency & \multicolumn{1}{c}{ Rel. } & \multicolumn{1}{c}{ Cum. } \\
\hline 1 & 81 & $46.29 \%$ & $46.29 \%$ \\
2 & 57 & $32.57 \%$ & $78.86 \%$ \\
3 & 36 & $20.57 \%$ & $99.43 \%$ \\
4 & 1 & $0.57 \%$ & $100.00 \%$ \\
\hline
\end{tabular}

From the regression results in table 4 , it is concluded that only the gender variable is proven to influence career maturity. In contrast, the two other variables, namely academic achievement, and unconfirmed social status, have a significant effect on career maturity. The gender variable has a p-value of 0.0516 , with a coefficient of -2.6905 . The p-value indicates that gender influences career maturity.

Table 4 Regression result, dependent variable: career maturity

\begin{tabular}{lrrrr}
\hline Variable & Coefficient & Std. Error & t-ratio & p-value \\
\hline const & 42.0787 & 10.5078 & 4.005 & $<0.0001$ \\
Academic Achievement & 4.26869 & 3.00796 & 1.419 & 0.1577 \\
Dummy Gender & -2.69048 & 1.37277 & -1.960 & 0.0516 \\
Dummy socio-economic_1 & -1.47341 & 1.44043 & -1.023 & 0.3078 \\
Dummy socio-economic_2 & -0.224781 & 1.17283 & -0.1917 & 0.8482 \\
\hline
\end{tabular}

The difference in career maturity between female and male students is confirmed in this study. These results also confirm research conducted by Luzzo (1995) that "there are differences in career maturity between male and female students." In the context of the career maturity of economics students, it turns out that the level of career maturity of a student can be seen from their gender.

The coefficient value of the variable career maturity is negative in this study because the quantification of the male gender is number 1 . At the same time, the female is number 0 , indicating that the career maturity of female students is better than male students. Conclusions of research such as those by Lee (2001) Patton and Creed (2003), which state that the career maturity of women is better than men are confirmed in this study. Conclusions from the study of Yon et al. (2013) can be valuable information about why this can happen, where female students have a higher interest in finding information about jobs and skills that must be possessed for their future.

The level of career maturity of female students who are better than men still does not guarantee that their careers in the future can develop better; there are still many obstacles that must be faced by women in developing their careers. Although women have a high 
desire to improve their career, they have to deal with obstacles that almost all women will face, namely: less personal time burdens, enormous responsibilities for caring for families, and lack of extra work time opportunities (Ismail and Ibrahim 2008; Matot et al. 2020).

Views of the society about gender in certain occupations have not changed, especially in the Asian region (Ronald, Susan, and Debra 2006). Many of them still hold the traditional view that some jobs are not optimal when done by women. "Career barriers identified by women in academic operations are very complex and include cultural factors from within and outside the profession, as well as other practical factors" (Tlaiss and Kauser 2010). Identifying and dismantling barriers, especially those that harm perceptions of ownership, is crucial for creating a culture of sustainable excellence (Cochran, Neumayer, and Elder 2019). However, women today are part of a precious resource for the survival of the world economy.

Efforts to support women's career development must not only be made in the learning process but still need to be done after a period of work, or work environment should be able to support women's career development (Eyigör et al. 2020; Kitada and Harada 2019). All parties must have an active role in supporting women's career development. Both in an academic environment, where they are still preparing for their future and in a work environment, where they must have a significant contribution.

The correlation between career maturity and academic achievement can be seen from the p-value of Academic Achievement. The results of the regression analysis stated that the Academic Achievement p-value was 0.1577, and the regression coefficient value was 4.26869. From the p-value, it can be seen that academic achievement does not significantly influence career maturity. The results of this study support research conducted by Roth and Clarke (1998), which states that the level of academic achievement does not reflect one's work performance. This matter might be due to the measurement of academic achievement that uses Academic Achievement which does not yet reflect one's abilities. Lei, Bassiri, and Schultz (2001) state that in determining Academic Achievement, there are differences in assessment criteria between one teacher and another. So, there is a possibility that grades can increase without being accompanied by an increase in students' abilities.

Another reason that is closer to career maturity is that many students think that Academic Achievement is not essential to them. They tend to pay attention to how they play a role in career achievement. The perceived role in learning related to a planned career was a more substantial effect than the value of the course (Peteranetz et al. 2018). Although many have found that adolescents with a secure future orientation, who have invested in career planning activities tend to perform better in school and vice versa, high academic achievement further reinforces the positive outlook of teens about their vocational future. However, it turns out that in the longitudinal perspective, the relationship between career maturity and academic achievement proves the opposite, there are no significant links. These longitudinal relationship patterns apply to male and female students (NegruSubtirica and Pop, 2016).

In the long run, academic achievement is also not very important in one's career development. "A high-performance orientation protects potential negative influences from low levels of academic competence and value on career satisfaction" (van Dierendonck and van der Gaast 2013).

The social status in this study was also not confirmed to have a significant effect on a person's career maturity. This matter can be seen from the p-value of 0.3078 , where the value is higher than the alpha value, so ho is not rejected and ha must be rejected. Social status has a 
regression coefficient of -1.44734 , which means that social status harms career maturity, although it is not significant. This conclusion is consistent with the analysis of research conducted by previous researchers, the career maturity of students from various levels of social status is relatively the same, or there is no real difference. However, students from higher socioeconomic status have lower career maturity levels (Rinanda and Ghofur, 2019).

Although the research of Yon, Choi, and Goh (2013) proves that gender and socioeconomic status variables correlate with one's career maturity, conclusions in some other studies show that there is indeed often a difference. In Sweden, the original social position is a less significant predictor of the level of education a person attains and the socioeconomic or occupational position (Sorjonen et al. 2012)

Although this study did not find a strong relationship between socioeconomic status and career maturity, it must remain a concern because there is a possibility that those from the lower classes have limited access to the network. Behtoui and Neergaard's (2012) research proves that socioeconomic background and gender have an impact on their access to a network of valuable resources. What should be of concern to the university is how to equip students with the ability to adapt well in the work environment. This ability to adapt is essential in the success of work (Monteiro, Taveira, and Almeida 2019).

For students from high economic backgrounds, the current career maturity tends to be lower than for students with lower socioeconomic status, because they have not found the right view on the future of their current job. They pay more attention to salary levels, future financial prospects, and job security because they are used to having a high standard of living (Ayodele 2019).

\section{CONCLUSION}

The results of the data analysis showed that the socioeconomic status variable and academic achievement did not influence the career maturity of the students of the Faculty of Economics, Universitas Negeri Surabaya. This matter is because academic achievement, as measured by the latest Academic Achievement Index, does not yet reflect the true abilities of students. The gender variable influences the career maturity of students of the Faculty of Economics, Universitas Negeri Surabaya, although the effect is not too significant. For further research, it is expected that the variables that affect the career maturity of students who have not been considered in this study, for example, variables of self-efficacy, age, parental support, and attitude will be considered.

There are some limitations to this study. Firstly, research samples are limited to only four courses that exist in the Faculty of Economics and dominated by female students. Further research expected to develop research with a balanced proportion between female and male participants. Secondly, an academic prestige indicator uses the Academic Achievement Index. The provision of value feared there are significant elements of the subjectivity of each lecturer. So, it is feared that the Academic Achievement Index has not been able to represent real academic achievements. Therefore, subsequent research should use other variables to measure student academic achievements. Thirdly, this study only examines variables that are socioeconomic status, gender difference, and academic achievement. Advice for further research would be to examine other variables that have not been studied in this research. Recommended variables include: the parent's foster pattern variable, the number of times parents use to discuss student future careers, locus of control, age, and peer support. 
Acknowledgement: The paper is a part of the research done within the project $569 /$ UN38/HK/PM/ 2019. The authors would like to thank the Head of Universitas Negeri Surabaya and Dean of the Faculty of Economics and Business, Universitas Negeri Surabaya, because they have funded and provided facilities of this research.

\section{REFERENCES}

Ayodele, T. O. (2019). Career choice of real estate students in Nigeria: The explaining influences in comparative perspective. Property Management, 37(1), 154-176. https://doi.org/10.1108/PM-02-2018-0013

Behtoui, A., \& Neergaard, A. (2012). Social capital, status and income attainment in the workplace. International Journal of Sociology and Social Policy, 32, 42-55. https://doi.org/10.1108/01443331211201752

Chhinzer, N., \& Russo, A. M. (2018). An exploration of employer perceptions of graduate student employability. Education and Training, 60(1), 104-120. https://doi.org/10.1108/ET-06-2016-0111

Choi, S., Hutchison, B., Lemberger, M. E., \& Pope, M. (2012). A Longitudinal Study of the Developmental Trajectories of Parental Attachment and Career Maturity of South Korean Adolescents. The Career Development Quarterly, 60(2), 163-177. https://doi.org/10.1002/j.2161-0045.2012.00014.x

Cobb, B., \& Yvette, Y. (2008). An analysis of the career maturity levels of intellectually gifted adolescents. University of Southern Mississippi.

Cochran, A., Neumayer, L. A., \& Elder, W. B. (2019). Barriers to careers identified by women in academic surgery: A grounded theory model. American Journal of Surgery, 218(4), 780-785. https://doi.org/10.1016/j. amjsurg.2019.07.015

Creed, P. A. (2001). Developmental Issues in Career Maturity and Career Decision Status. The Career Development Quarterly, 49(June).

Crites, J. O. (1973). Career Maturity. NCME Measurement in Education, 4(2), 1-8.

Crites, J. O., \& Savickas, M. L. (1996). Revision of the Career Maturity Inventory. Journal of Career Assessment, 4(2), 131-138. https://doi.org/10.1177/106907279600400202

Eyigör, H., Can, İ. H., İncesulu, A., \& Șenol, Y. (2020). Women in otolaryngology in Turkey: Insight of gender equality, career development and work-life balance. American Journal of Otolaryngology - Head and Neck Medicine and Surgery, 41(1), 102305. https://doi.org/10.1016/j.amjoto.2019.102305

Gottfredson, L. S. (2002). Gottfredson's theory of circumscription, compromise, and self-creation. In D. Brown (Ed.), Career choice and development (4th ed., pp. 85-148). New York: Jossey-Bass.

Heo, G., \& Kim, T. (2016). Autoregressive Cross-Lagged Modeling of the Reciprocal Longitudinal Relationship Between Self-Esteem and Career Maturity. Journal of Career Development, 43(3), $273-288$. https://doi.org/10.1177/0894845315598002

Hsieh, H. H., \& Huang, J. T. (2014). The effects of socioeconomic status and proactive personality on career decision self-efficacy. Career Development Quarterly, 62(1), 29-43. https://doi.org/10.1002/j.21610045.2014.00068.x

Ismail, M., \& Ibrahim, M. (2008). Barriers to career progression faced by women: Evidence from a Malaysian multinational oil company. Gender in Management, 23(1), 51-66. https://doi.org/10.1108/17542410810849123

Janeiro, I. N. (2010). Motivational dynamics in the development of career attitudes among adolescents. Journal of Vocational Behavior, 76(2), 170-177. https://doi.org/10.1016/j.jvb.2009.12.003

Jawarneh, M. (2016). Career maturity among university students in Jordan: The case for social studies. Australian Journal of Career Development, 25(3), 110-116. https://doi.org/10.1177/1038416216676807

Kim, J. H., \& Shin, H. S. (2020). Effects of self-reflection-focused career course on career search efficacy, career maturity, and career adaptability in nursing students: A mixed methods study. Journal of Professional Nursing. https://doi.org/10.1016/j.profnurs.2020.03.003

Kitada, M., \& Harada, J. (2019). Progress or regress on gender equality: The case study of selected transport STEM careers and their vocational education and training in Japan. Transportation Research Interdisciplinary Perspectives, 1, 100009. https://doi.org/10.1016/j.trip.2019.100009

Koumoundourou, G. A., Kounenou, K., \& Siavara, E. (2012). Core Self-Evaluations, Career Decision SelfEfficacy, and Vocational Identity Among Greek Adolescents. Journal of Career Development, 39(3), 269286. https://doi.org/10.1177/0894845310397361

Lee, H. Y., \& Hughey, K. F. (2001). The relationship of psychological separation and parental attachment to the career maturity of college freshmen from intact families. Journal of Career Development, 27(4), 279-293. https://doi.org/10.1023/A:1007855104473

Lee, K. (2001). A Cross-Cultural Study of the Career Maturity of Korean and United States High School Students. Journal of Career Development, 28, 43-57. 
Lei, P.-W., Bassiri, D., \& Schultz, E. M. (2001). Alternatives to the Grade Point Average as a Measure of Academic Achievement in College.

Lent, R. W. (2013). Social Cognitive Career Theory. In S. D. Brown \& R. W. Lent (Eds.), Career Development and Counseling: Putting Theory and Research to Work (2nd ed., pp. 115-146). Hoboken, NJ: John Wiley \& Sons, Inc.

Luzzo, D. A. (1995). Gender Differences in College Students' Career Maturity and Perceived Barriers in Career Development. Journal of Counseling \& Development, 73(February), 63-66.

Matot, I., De Hert, S., Cohen, B., \& Koch, T. (2020). Women anaesthesiologists' attitudes and reported barriers to career advancement in anaesthesia: a survey of the European Society of Anaesthesiology. British Journal of Anaesthesia, 124(3), e171-e177. https://doi.org/10.1016/j.bja.2020.01.005

Metheny, J., \& McWhirter, E. H. (2013). Contributions of Social Status and Family Support to College Students' Career Decision Self-Efficacy and Outcome Expectations. Journal of Career Assessment, 21(3), 378-394. https://doi.org/10.1177/1069072712475164

Monteiro, S., Taveira, M. do C., \& Almeida, L. (2019). Career adaptability and university-to-work transition: Effects on graduates' employment status. Education and Training, 61(9), 1187-1199. https://doi.org/ 10.1108/ET-10-2018-0206

Negru-Subtirica, O., \& Pop, E. I. (2016). Longitudinal links between career adaptability and academic achievement in adolescence. Journal of Vocational Behavior, 93, 163-170. https://doi.org/10.1016/j.jvb. 2016.02.006

Patel, S. G., Salahuddin, N. M., \& O'Brien, K. M. (2008). Career decision-making self-efficacy of Vietnamese adolescents: The role of acculturation, social support, socioeconomic status, and racism. Journal of Career Development, 34 (3), 218-240. https://doi.org/10.1177/0894845307308488

Patton, W., \& Creed, P. A. (2001). Developmental Issues in Career Maturity and Career Decision Status. The Career Development Quarterly, 49(4), 336-351. https://doi.org/10.1002/j.2161-0045.2001.tb00961.x

Patton, W., \& Creed, P. A. (2002). The relationship between career maturity and work commitment in a sample of Australian high school students. Journal of Career Development, 29(2), 69-85. https://doi.org/10.1177/ 089484530202900201

Peter, A. C., \& Wendy, P. (2003). Predicting Two Components of Career Maturity in School Based Adolescents. Journal of Career Development, 29(4), 277-290.

Peteranetz, M. S., Flanigan, A. E., Shell, D. F., \& Soh, L. K. (2018). Career aspirations, perceived instrumentality, and achievement in undergraduate computer science courses. Contemporary Educational Psychology, 53, 27-44. https://doi.org/10.1016/j.cedpsych.2018.01.006

Rinanda, T. R., \& Ghofur, M. A. (2019). Analisa Kematangan Karir Mahasiswa Pendidikan Ekonomi Ditinjau Dari Status Sosial Ekonomi Keluarga. PROMOSI: Jurnal Program Studi Pendidikan Ekonomi, 7(1). https://doi.org/10.24127/PRO.V7I1.2033

Ronald, B., Susan, M., \& Debra, N. (2006). Barriers women face in information technology careers: Self-efficacy, passion and gender biases. Women in Management Review, 21(1), 10-27. https://doi.org/10.1108/ 09649420610643385

Roth, P. L., \& Clarke, R. L. (1998). Meta-Analyzing the Relation between Grades and Salary. Journal of Vocational Behavior, 53(3), 386-400. https://doi.org/10.1006/jvbe.1997.1621

Rothman, M. (2017). Employer assessments of business interns. Higher Education, Skills and Work-Based Learning, 7(4), 369-380. https://doi.org/10.1108/HESWBL-05-2017-0029

Rugutt, J., \& Chemosit, C. (2005). A Study of Factors that Influence College Academic Achievement: A Structural Equation Modeling Approach. Journal of Educational Research \& Policy Studies, 5(1), 66-90.

Savickas, M. L., \& Porfeli, E. J. (2011). Revision of the career maturity inventory: The adaptability form. Journal of Career Assessment, 19(4), 355-374. https://doi.org/10.1177/1069072711409342

Shin, Y. J., \& Lee, J. Y. (2018). Predictors of Career Decision Self-Efficacy: Sex, Socioeconomic Status (SES), Classism, Modern Sexism, and Locus of Control. Journal of Career Assessment, 26(2), 322-337. https://doi.org/10.1177/1069072717692981

Sirin, S. R. (2005). Socioeconomic status and academic achievement: A meta-analytic review of research. Review of Educational Research, 75(3), 417-453. https://doi.org/10.3102/00346543075003417

Sorjonen, K., Hemmingsson, T., Lundin, A., Falkstedt, D., \& Melin, B. (2012). Intelligence, socioeconomic background, emotional capacity, and level of education as predictors of attained socioeconomic position in a cohort of Swedish men. Intelligence, 40(3), 269-277. https://doi.org/10.1016/j.intell.2012.02.009

Spurk, D., Kauffeld, S., Barthauer, L., \& Heinemann, N. S. R. (2015). Fostering networking behavior, career planning and optimism, and subjective career success: An intervention study. Journal of Vocational Behavior, 87, 134-144. https://doi.org/10.1016/j.jvb.2014.12.007

Stephen, P., \& Burke, M. (1994). The Learning Experience:: Student Perceptions and Evaluations. Librarian Career Development, 2(3), 11-13. https://doi.org/10.1108/09680819410066921 
Super, D. E. (1980). A life-span, life-space approach to career development. Journal of Vocational Behavior, $16,282-298$.

Super, D. E., \& Knasel, E. G. (1981). Career Development in Adulthood: Some Theoretical Problems and a Possible Solution. British Journal of Guidance \& Counselling, 9(2), 194-201. https://doi.org/10.1080/ 03069888108258214

Tlaiss, H., \& Kauser, S. (2010). Perceived organizational barriers to women's career advancement in Lebanon. Gender in Management, 25(6), 462-496. https://doi.org/10.1108/17542411011069882

van Dierendonck, D., \& van der Gaast, E. (2013). Goal orientation, academic competences and early career success. Career Development International, 18(7), 694-711. https://doi.org/10.1108/CDI-01-2013-0003

Yon, K. J., Choi, W., \& Goh, M. (2013). Career Maturity Growth Curve and Sex-Role Stereotypes of Korean Adolescents. Journal of Career Development, 40(3), 203-222. https://doi.org/10.1177/0894845312445515

\section{ANALIZA UTICAJA SOCIOEKONOMSKOG STATUSA, POLA I AKADEMSKIH POSTIGNUĆA NA NIVO KARIJERNE ZRELOSTI STUDENATA}

Karijerna zrelost se definiše kao sposobnost osobe da identifikuje i pripremi se za izbor karijere. Karijerna zrelost je neophodna studentima jer, što je nivo karijerne zrelosti veći, povećaće se i njihova postignuća u radu. Ova studija ima za cilj da odredi faktore koji utiču na karijernu zrelost studenata. Vrsta istraživanja koja je koriščena je korelaciono istraživanje sa kvantitativnim metodama. Podaci su sakupljeni korišćenjem metoda upitnika i tehnike analize podataka korišćenjem višestruke linearne regresije. Rezultati regresione analize pokazali su da vaijabla pola utiče na karijernu zrelost, dok akademsko postignuće i socioekonomski status nemaju značajnog uticaja na karijernu zrelost studenata.

Ključne reči: Karijerna zrelost, akademska postignuća, socioekonomski status 